\title{
Occurrence and impact of back pain on the quality of life of healthcare workers
}

\author{
Bożena Mroczek ${ }^{1, A-D, F \oplus}$, Wioletta Łubkowska ${ }^{2, C-D \oplus}{ }^{\circ}$, Wojciech Jarno ${ }^{3, B \oplus}$, Ewa Jaraczewska ${ }^{1, D \oplus}$, \\ Artur Mierzecki ${ }^{4, E-F} \oplus$ \\ ${ }^{1}$ Department of Human Sciences in Medicine, Pomeranian Medical University, Szczecin, Poland \\ ${ }^{2}$ Department of Physical Education and Health, University of Szczecin, Poland \\ ${ }^{3}$ Non-Public Health Care Institution - Physiotherapy DAKMED, Poland \\ ${ }^{4}$ Independent Laboratory of Family Physician Education, Pomeranian Medical University, Szczecin \\ A - Research concept and design, B - Collection and/or assembly of data, C - Data analysis and interpretation, \\ $D$ - Writing the article, $E$ - Critical revision of the article, F - Final approval of article
}

\begin{abstract}
Mroczek B, Łubkowska W, Jarno W, Jaraczewska E, Mierzecki A. Occurrence and impact of back pain on the quality of life of healthcare
\end{abstract} workers. Ann Agric Environ Med. 2020; 27(1): 36-42. DOI: 10.26444/aaem/115180

\section{Abstract}

Introduction and Objective. Back pain affects specific occupational groups, among which healthcare workers are the most predisposed. Therefore, the aim of this study was to determine the interdependences between subjective disability and their correlation with pain intensity and quality of life assessment among professionally active medical workers, taking into account working, socio-demographic and health conditions.

Materials and Method. The cross-sectional study enrolled 110 professionally active medical workers (nurses, midwives, paramedics and physiotherapists). The study was conducted by a diagnostic survey method using 4 questionnaires: Visual Analogue Scale (VAS), Oswestry Disability Index (ODI), World Health Organization Quality of Life BREF (WHOQoL-BREF), and the authors' questionnaire.

Results. Back pain was reported by 103 respondents (94\%) with the lumbar area indicated the most frequently (72.81\%). Severe pain every day was reported by $49.51 \%$ of respondents and was associated with longer working time. ODI questionnaire confirmed III and IV degrees of disability in paramedics and nurses, who additionally obtained the lowest results in the quality of life assessment. Correlations between age and VAS were demonstrated $(p=0.002)$, and between VAS and ODI pain $(p<0.0001)$ and ODI disability $(p<0.0001)$.

Conclusions. Back pain associated with professional activities is the consequence of overload. Health care workers should be included in a preventive programme and attend systematic ergonomics courses. Health care facilities should be retrofitted with equipment enabling work in accordance with the principles of ergonomics. The ODI questionnaire, together with the VAS method and scales for testing the quality of life, are useful tools in the clinical assessment of individuals with back pain.

\section{Key words}

quality of life, VAS, WHOQOL-BREF, Oswestry Disability Index, back pain syndrome, medical workers

\section{INTRODUCTION}

Back pain resulting from lifestyle is classified as social disease [1]. According to research conducted by the European Foundation for the Improvement of Living and Working Conditions, musculoskeletal system pain disorders involving mainly the spine, are the most common work-related health problem in the European Union [2]. They pose a serious medical and socio-economic burden which is noticeable in primary healthcare [3-6]. Lifetime prevalence of low back pain concerns more than $84 \%$ of the population and chronic back pain about $23 \%$, of which $11-12 \%$ are patients with disabilities [7]. Spinal pain is one of the main causes of psychophysical discomfort, impeding functioning in everyday life, and reducing self-esteem and the quality of life [8-11]. It results in work absence, and is the most common reason of inability to perform work and one of the main factors leading to physical disability [3, 4, 7, 12-14].

From the occupational medicine point of view, back pain can be classified as a work-related disease, depending on the

Address for correspondence: Wioletta Łubkowska Department of Physical Education and Health, University of Szczecin, Poland

E-mail:Wioletta.Lubkowska@usz.edu.pl

Received: 24.11.2019; accepted: 10.12.2019; first published: 30.12 .2019 exposure level of bending the torso or lifting and carrying weights [15]. This disease affects specific occupational groups, among which healthcare workers are the most predisposed [16]. The sixth European study on working conditions (n $=44,000$ ) carried out in 35 European countries showed that healthcare providers, including physiotherapists, nurses, midwives and paramedics are subjects of the highest work intensity [2]. At the same time, they are particularly exposed to injuries, musculoskeletal system long-term static and/or dynamic overloads and spine pain [17-22].

The type of work performed affects the spine and is associated with the need for forced long-term maintenance of often unnatural position of the body, resulting in muscle pain and back pain syndromes. Most of the professional activities of medical staff are repeated many times, performed in a standing position, with a bended or twisted torso, and involve lifting, especially during nursing activities and medical procedures [23]. The cervical and lumbar spine, upper limbs and feet are considered to be the most vulnerable areas [2]. The factor that additionally contributes to the development of back pain is the significantly extended working time of this professional group, compared to the statutory period. Employees who work for too long, at the expense of rest, have more psychophysical problems, including low back pain occurrence [24]. 
Ignoring the pain as a symptom from musculoskeletal system, translates into serious health consequences - from discomfort, through lowering the quality of life, to injuries and disability. This is accompanied by the threat of to the material existence of the employee and his family, rejection by relatives, sense of being a burden to others, and depression [2]. In the light of these data, it seems necessary to recognize the scale of overload and perceived discomfort, as well as their impact on the quality of life among healthcare workers, in order to take effective preventive and repair measures [16, 25].

\section{OBJECTIVE}

The aim of the study was to determine the interdependences between subjective disability and their correlation with pain intensity and quality of life assessment among professionally active medical workers (nurses, midwives, paramedics and physiotherapists), taking into account working, sociodemographic and health conditions.

\section{MATERIALS AND METHOD}

The cross-sectional study was conducted during the period from December 2017 - April 2018 in the West Pomeranian Province on northeastern Poland among 110 professionally active medical workers, currently employed, not on sick or health leave, recruited from various healthcare institutions. Equal numbers of physiotherapists, nurses, midwives and paramedics, whose work activities include forced position, lifting weights, long standing, and computer use, were invited to participate in the study.

The research was carried out in accordance with the requirements of the Helsinki Declaration of 1975 (amendment of 2000) and Good Clinical Practice. Before the study, all participants were informed about its purpose. They were assured of the anonymity and voluntary nature of participating in the study, and of the possibility to resign from participation at any stage. Returning the completed questionnaire was tantamount to the patient's consent for participation.

Participants. A group of 110 professionally active medical workers, whose working activities involve spine overload, were selected for preliminary assessment. The study sample included: 28 physiotherapists (24.5\%), 27 nurses (25\%), 25 midwives $(22.7 \%)$ and 30 paramedics $(27 \%)$. This group consisted mostly of woman - 85 (77\%) and 71 (65\%) young adults aged 22-35. The youngest professional subgroup were physiotherapists ( $34 \pm 7$ years), and the oldest were nurses (36 \pm 10 years). Over half of the respondents, 64 (58\%), declared employment in one place of work, and 45 individuals (41\%) were employed in two or more places of work. (Tab. 1).

The study was conducted by the method of diagnostic survey using 4 questionnaires: Visual Analogue Scale (VAS), Oswestry Disability Index (ODI), World Health Organization Quality of Life BREF (WHOQoL-BREF) instrument - in the Polish language version, and the authors' questionnaire on demographic and health data.

Visual Analogue Scale (VAS). Used to assess pain and its severity on a scale of $0-10$. The tested subject, using a straight horizontal line with a length of $10 \mathrm{~cm}$, indicates the level of pain felt. The researcher then marks the indicated point. Range of $0-3$ signifies no pain or weak pain, $4-6$ signifies severe pain, and $7-10$ a very strong to the strongest pain imaginable [26].

Oswestry Disabillity Index (ODI). is the method for assessing disability caused by back pain. It contains 10 questions regarding: the intensity of pain and its variability, selfreliance, weight lifting, ability to travel, sexual intercourse, rising from a sitting position, sleeping, walking, standing and sitting. Questions are scored on a scale of 0 to 5 . The maximum number of points is 50 . The result is presented on a scale of $0-50$ points or as a percentage from $0-100 \%$. Using Fairbank's interpretation of ODI results, on a scale of $0-100 \%$, five disability groups are determined: minimal $0-20 \%$, moderate $21-40 \%$, severe $41-60 \%$, very serious $61-$ $80 \%$ and exaggerated symptoms $81-100 \%$ [27].

WHOQoL-BREF instrument. Assesses the quality of life of both healthy and sick individuals. It consists of 26 questions enabling the assessment of 4 areas of life: social, physical, psychological and environmental. The questionnaire contains 2 question, analyzed separately, concerning assessment of the quality of life satisfaction and health. The number of points that can be achieved range from $0-100$. The higher the number of points obtained in the questionnaire, the better the quality of life [28].

Authors' questionnaire. Consisted of 15 questions concerning socio-demographic data, such as: age, gender, place of residence, workplace and working conditions, as well as health problems - perceived back pain and co-existing chronic diseases.

Statistical analysis. The obtained results were evaluated by the IBM SPSS Statistics v. 25 package. The following were used for the analysis: Shapiro-Wilk test to assess the normality of variable distribution, Mann-Whitney U test, Kruskal-Wallis test, $\mathrm{Chi}^{2}$ test with Fisher's exact test for $2 \times 2$ tables and rhoSpearman correlations. The value of $\mathrm{p}<0.05$ was used as the indicator of statistical significance. Cronbach's alpha test was used for the reliability analysis of the ODI scale, which was 0.877 .

\section{RESULTS}

The vast majority of respondents (81\%) worked in a forced position, with the average number of hours totalling $3.5 \pm 2.4$. Nurses are the subgroup with the longest duration of this position $(4.7 \pm 2.43)$ (Table 1$)$. Back pain in one or several sections of the spine was reported by 103 respondents (94\%) (Table 2). The lumbar section of the spine was most frequently indicated as painful was (75 individuals - 72.81\%), and less frequently the cervical section (40 individuals - 38.83\%), thoracic (33 individuals $-32.03 \%$ ) and sacral (27 individuals - 26.2\%) sections. Physiotherapeutic procedures to reduce pain were used by 40 participants (38.83\%).

Perception of pain measured by VAS. Very strong to the strongest pain imaginable experienced every day (7-10 points) was reported by $12.52 \%$ of respondents, severe pain 
Table 1. Socio-demographic characteristics of the sample $(\mathrm{N}=110)$

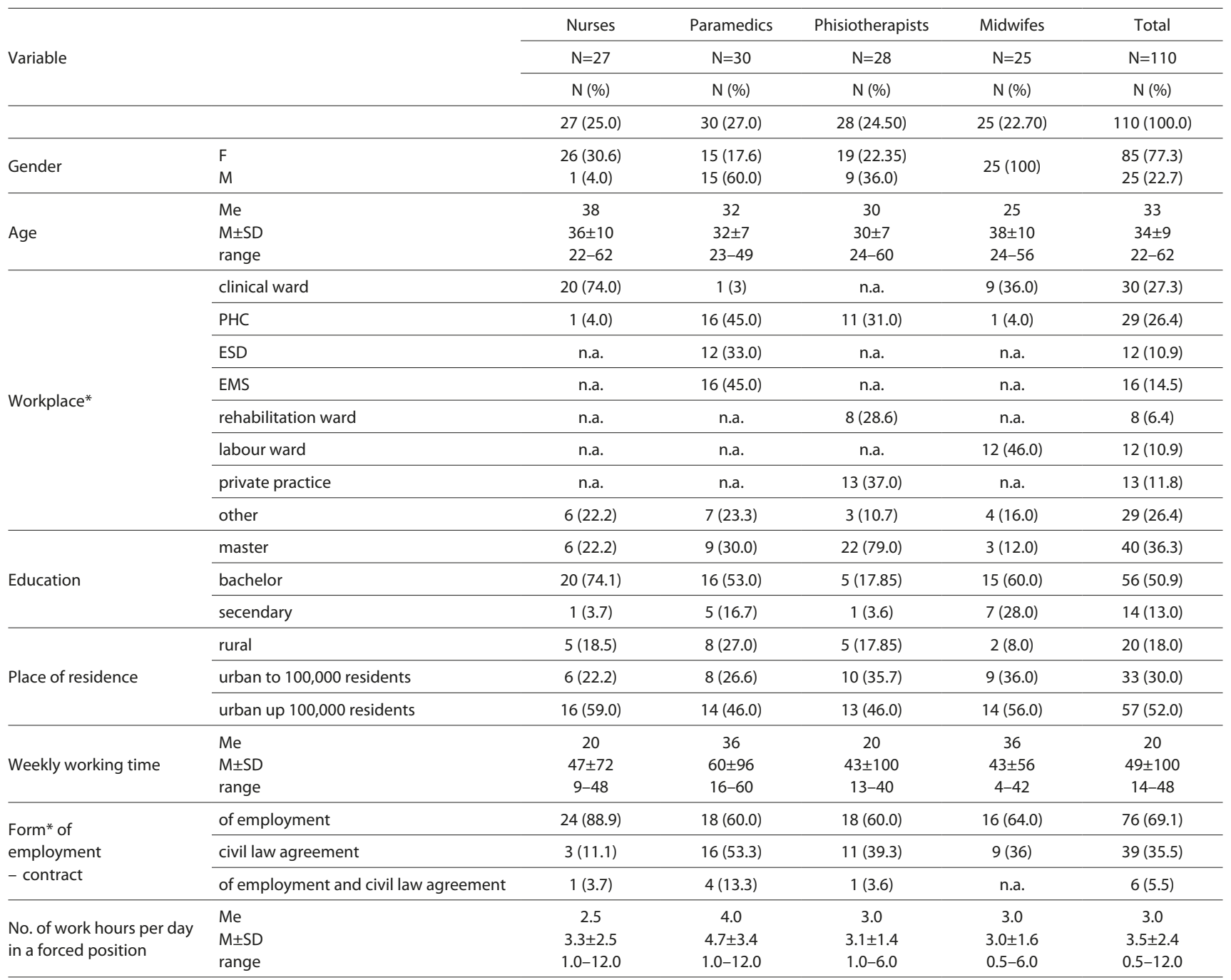

Me - median; M - average; SD - standard deviations; n.a. - non applicable; PHC - Primary Health Care; ESD - Emergency Specialist Department; EMS - Emergency Medical Services; ${ }^{*}$ More than one category was indicated

(4-6 points) by $49.51 \%$, and weak or no pain ( $0-3$ points) by $37.86 \%$. Individuals, who experienced back pain worked more than 40 hours a week - 64 (62.7\%). Statistical significance

Table 2. Occurrence of back pain including variables.

\begin{tabular}{llll}
\hline \multirow{2}{*}{ Variables } & & \multicolumn{3}{c}{ Yes } \\
\cline { 2 - 4 } & & $\mathrm{N}$ & $\%$ \\
\hline \multirow{4}{*}{ Occupation } & nurses & 25 & 92.6 \\
\cline { 2 - 4 } & paramedics & 28 & 93.3 \\
\cline { 2 - 4 } & physiotherapists & 28 & 100.0 \\
\cline { 2 - 4 } Age & midwives & 22 & 88.0 \\
\hline \multirow{3}{*}{ Gender } & $22-35$ years & 67 & 94.0 \\
\cline { 2 - 4 } & $36-48$ years & 30 & 94.1 \\
\cline { 2 - 4 } & $49-62$ years & 6 & 85.7 \\
\hline \multirow{3}{*}{ Weekly working time } & female & 80 & 94.1 \\
\cline { 2 - 4 } & male & 23 & 92.0 \\
\hline & $20-40 \mathrm{~h}$ & 38 & 95.0 \\
\cline { 2 - 4 } & $41-60 \mathrm{~h}$ & 14 & 87.5 \\
\cline { 2 - 4 } & $>60 \mathrm{~h}$ & & 96.2 \\
\hline
\end{tabular}

was demonstrated between pain perception, number of workplaces $\left(\mathrm{Chi}^{2}=21.11 ; \mathrm{p}=0.001\right)$ and secondary education $\left(\mathrm{Chi}^{2}=8.06 ; \mathrm{p}=0.02\right)$. Respondents working in more than one workplace and those with secondary education experienced more often moderate to severe back pain. These differences were statistically significant.

Pain intensity and disability rating according to ODI. A statistically significant correlation was found between the degree of ODI disability and occupation, education and the use of physiotherapist's health services $(\mathrm{p}<0.005)$. Disability of III and IV degrees occurred in nurses and paramedics $\left(\mathrm{Chi}^{2}=17.09 ; \mathrm{p}=0.05\right)$ and subjects with a lower level of education $\left(\mathrm{Chi}^{2}=12.52 ; \mathrm{p}=0.05\right)$. A physiotherapist's health services were used more often by individuals with II and IV degrees of disability $\left(\mathrm{Chi}^{2}=8.382 ; \mathrm{p}=0.04\right)$. The median ODI points for the study group was $\mathrm{Me}=8,8.7 \pm 6.6$, range $0-31$, which indicates minimal disability according to Fairbank. Correlations between pain intensity, change in pain intensity and other ODI categories are shown in Table 3.

WHOQoL-BREF quality of life assessment. The median overall quality of life was 65.63 , mean $65.11 \pm 9.74$, range 
Table 3. Correlations between disability categories according to ODI scale.

\begin{tabular}{|c|c|c|c|c|c|c|c|c|c|c|c|}
\hline \multicolumn{12}{|c|}{ Oswestry Disability Index Questions } \\
\hline & & 1 & 2 & 3 & 4 & 5 & 6 & 7 & 8 & 9 & 10 \\
\hline \multirow{2}{*}{ 1) pain intensity } & r & 1 & .438 & .381 & .359 & .350 & .544 & .451 & .492 & .428 & .642 \\
\hline & $\mathrm{p}$ & & $<.0001$ & $<.0001$ & $<.0001$ & $<.0001$ & $<.0001$ & $<.0001$ & $<.0001$ & $<.0001$ & $<.0001$ \\
\hline \multirow{2}{*}{ 2) sleeping } & $r$ & & 1 & .456 & .296 & .362 & .271 & .474 & .505 & .525 & .447 \\
\hline & $\mathrm{p}$ & & & $<.0001$ & .002 & $<.0001$ & .004 & $<.0001$ & $<.0001$ & $<.0001$ & $<.0001$ \\
\hline 3) lifting weights & $\mathrm{p}$ & & & & .02 & .001 & $<.0001$ & $<.0001$ & $<.0001$ & $<.0001$ & $<.002$ \\
\hline \multirow{2}{*}{ 4) walking } & $r$ & & & & 1 & .225 & .410 & .440 & .676 & .381 & .349 \\
\hline & $\mathrm{p}$ & & & & & .018 & $<.0001$ & $<.0001$ & $<.0001$ & $<.0001$ & $<.0001$ \\
\hline \multirow{2}{*}{ 5) sitting } & $r$ & & & & & 1 & .503 & .374 & .445 & .474 & .424 \\
\hline & $\mathrm{p}$ & & & & & & $<.0001$ & $<.0001$ & $<.0001$ & $<.0001$ & $<.0001$ \\
\hline 6) standing & $\mathrm{p}$ & & & & & & & $<.0001$ & $<.0001$ & $<.0001$ & $<.0001$ \\
\hline \multirow{2}{*}{ 7) personal care } & $r$ & & & & & & & 1 & .645 & .508 & .445 \\
\hline & $\mathrm{p}$ & & & & & & & & $<.0001$ & .0001 & $<.0001$ \\
\hline \multirow{2}{*}{ 8) sex life } & $r$ & & & & & & & & 1 & .515 & .478 \\
\hline & $\mathrm{p}$ & & & & & & & & & .0001 & $<.0001$ \\
\hline \multirow{2}{*}{ 9) travelling } & r & & & & & & & & & 1 & .488 \\
\hline & $\mathrm{p}$ & & & & & & & & & & $<.0001$ \\
\hline \multirow{2}{*}{ 10) change in pain intensity } & $r$ & & & & & & & & & & 1 \\
\hline & $p$ & & & & & & & & & & \\
\hline
\end{tabular}

$r$ - Pearson correlation; $p$ - significance level.

1) pain intensity; 2) sleeping;3) lifting weights.; 4) walking; 5) sitting; 6) standing;7) personal care; 8) sex life;

9) travelling; 10) change in pain intensity.

(39.0-83.0). The lowest rating of quality of life was observed in the environmental domain $(\mathrm{Me}=63.0)$, and the highest in the social domain ( $\mathrm{Me}=75.0$, range: $6.0-100.0)$. A statistically significant result was obtained for a variable of working time and a higher number of working hours in relation to the environmental domain $(\mathrm{p}=0.006)$. The higher the education level of the respondents, the better their overall quality of life $(\mathrm{p}=0.02)$ in the physical $(\mathrm{p}=0.006)$ and psychological $(p=0.04)$ domains. Nurses rated their quality of life as the worst in terms of general $(p=0.05)$, social $(p=0.007)$ and environmental $(\mathrm{p}=0.006)$ domains.

The quality of life rating was compared with disability according to ODI, age, working time and assessment of

Table 4. Value of regression beta coefficients for the model assessing the impact of individual variables on obtained score in the psychological, social, environmental and somatic domains, as well as overall quality of life assessmen.

\begin{tabular}{|c|c|c|c|c|c|c|c|c|}
\hline \multirow{3}{*}{$\begin{array}{l}\text { WHOQOL-BREF } \\
\text { domain }\end{array}$} & \multicolumn{8}{|c|}{ Indepedent variable } \\
\hline & \multicolumn{2}{|c|}{ Age } & \multicolumn{2}{|c|}{ Hours of work } & \multicolumn{2}{|c|}{ VAS } & \multicolumn{2}{|c|}{ ODI } \\
\hline & b & $\mathrm{p}$ & b & $\mathrm{p}$ & $\mathrm{b}$ & $\mathrm{p}$ & b & $\mathrm{p}$ \\
\hline Psychological & -.077 & .60 & .185 & .06 & -.45 & .576 & -.36 & .006 \\
\hline Social Relationships & -.091 & .66 & .119 & .39 & 1.14 & .301 & -.28 & .128 \\
\hline Environmental & -.134 & .27 & .140 & .08 & .85 & .183 & .005 & .958 \\
\hline Physical Health & -.168 & .16 & .039 & .62 & -.71 & .267 & -.59 & .0001 \\
\hline WHOQOL-BREF total & .005 & .96 & .121 & .05 & .21 & .673 & -.30 & .0001 \\
\hline
\end{tabular}

perceived pain using VAS (Tab. 4). Statistical significance was demonstrated between the overall assessment of quality of life in psychological together with somatic domains, and the level of ODI disability. Correlation between the physical domain and ODI was $-\sqrt{t}=-0.413 ; \mathrm{p}<0.0001$. The lower the disability level according to ODI, the higher the quality of life in the physical domain. Table 5 shows the correlations between ODI assessed disability and VAS pain intensity assessment in relation to WHOQOL-BREF quality of life evaluation including variables. Correlations between age and VAS were demonstrated with increasing age; pain intensity was higher $(\mathrm{t}=0.22, \mathrm{p}=0.002)]$ and between VAS and ODI pain $(\mathrm{p}<0.0001)$ and ODI disability $(\mathrm{p}<0.0001)$. The higher the level of disability, the worse the quality of life.

\section{DISCUSSION}

Lower back pain is recognized in developed countries as a common cause of morbidity in various occupational situations, especially in healthcare professionals, doctors, nurses, physiotherapists, paramedics and midwives [2]. This study has shown that spine disorders, pain and limitations occurred in the majority of surveyed medical workers, which was associated with a decrease in their quality of life. These complaints are particularly evident in nurses and paramedics. The majority of the evaluated group perceived pain each day, which was associated with working over 40 hours a week in several places. The forced position taken during working activities by most of the respondents (80\%) for an average 3.5 hours a day, had a great impact on the perception of pain and 
Table 5. Correlations between disability assessed by ODI, and pain intensity according to ODI and VAS, in relation to quality of life WHOQOL-BREF evaluation

\begin{tabular}{|c|c|c|c|c|c|c|c|c|c|c|}
\hline & & VAS & Phd & $\mathrm{Pd}$ & SRd & Ed & $\begin{array}{l}\text { ODI } \\
\text { pain }\end{array}$ & Education & Number of workplaces & ODI scale \\
\hline Age & $\mathrm{t}$ & 0.22 & 0.004 & 0.04 & -0.04 & -0.007 & 0.16 & -0.22 & -0.12 & 0.12 \\
\hline \multirow{2}{*}{ Hours of work } & $\mathrm{t}$ & 0.05 & -0.04 & 0,086 & -0.03 & 0.16 & 0.11 & -0.07 & 0.43 & 0.04 \\
\hline & $\mathrm{p}$ & 0.53 & 0.55 & 0,232 & 0.7 & 0.03 & 0.13 & 0.37 & $<0.0001$ & 0.6 \\
\hline VAS & $\mathrm{p}$ & - & $<.0001$ & 0.02 & 0.81 & 0.16 & $<.0001$ & 0.05 & 0.18 & $<.0001$ \\
\hline \multirow{2}{*}{ PHd - Physical Health domain } & $\mathrm{t}$ & & & 0.412 & 0.14 & 0.01 & -0.39 & 0.16 & 0.06 & -0.41 \\
\hline & $\mathrm{p}$ & - & - & $<.0001$ & 0.05 & 0.88 & $<.0001$ & 0.05 & 0.47 & $<.0001$ \\
\hline \multirow{2}{*}{ Pd - Psychological domain } & $\mathrm{t}$ & & & & 0.15 & 0.09 & -0.21 & 0.13 & -0.02 & -0.22 \\
\hline & $\mathrm{p}$ & - & - & - & 0.04 & 0.19 & 0.003 & 0.11 & 0.84 & 0.01 \\
\hline \multirow{2}{*}{ SRd - Social Relationships domain } & $\mathrm{t}$ & & & & & 0.04 & -0.07 & 0.13 & -0.06 & -0.102 \\
\hline & $\mathrm{p}$ & - & - & - & - & 0.58 & 0.32 & 0.11 & 0.45 & 0.212 \\
\hline \multirow{2}{*}{ Ed - Environmental domain } & $\mathrm{t}$ & & & & & & 007 & -0.03 & 0.11 & 0.066 \\
\hline & $\mathrm{p}$ & - & - & - & - & - & 0.32 & 0.69 & 0.17 & 0.416 \\
\hline \multirow{2}{*}{ ODI pain } & $\mathrm{t}$ & & & & & & & -0.20 & -0.07 & 0.711 \\
\hline & $\mathrm{p}$ & - & - & - & - & - & - & 0.01 & 0.34 & $<.0001$ \\
\hline \multirow{2}{*}{ Education } & $t$ & & & & & & & & 0.15 & -0.16 \\
\hline & $\mathrm{p}$ & - & - & - & - & - & - & - & 0.09 & 0.07 \\
\hline
\end{tabular}

$\mathrm{t}$ - Kendall's Tau coefficient; $\mathrm{p}$ - significance level; ODI - Oswestry Disability Index - pain or scale.

VAS - Visual Analog Scale; PHd - Physical Health domain; Pd - Psychological domain; SRd - Social Relationships domain; Ed -Environmental domain.

the level of disability. These results were influenced i.a. by the workplace infrastructure, not adapted to working activities in many cases (e.g. hospital beds without the possibility of height adjustment according to the employee's height). ODI questionnaire confirmed III and IV degrees of disability in nurses and paramedics.

Kuijer et al. reviewed systematically the risk factors for work-related back pain [15]. Their meta-analysis revealed significant associations of lumbosacral radiculopathy syndrome (LRS) with physical work, bending/twisting the torso, lifting and carrying together with simultaneously bending/twisting the torso. In their conclusions, the researchers stated that LRS can be considered a workrelated disease depending on the exposure degree to the aforementioned activities [15]. Coenen et al. showed similar results regarding the association of lower back pain with lifting and carrying [29]. Based on another meta-analysis, they determined that the risk of lower back pain incidence is associated with different levels of work-related exposure, such as weight and lifting frequency. That risk assessment should form the basis of a health policy at the workplace [29]. Therefore, based on statistical data and scientific reports, in Poland a programme was adopted, aimed at the prevention and early detection of lower back pain among professionally active citizens [30].

The current study found minimal disability according to Fairbank, among the analysed group. Correlations between ODI, VAS and WHOQOL-BREF distinguished appropriately the factors related to the occupation that caused pain and disability involving the musculoskeletal system. Nurses obtained the lowest results in the assessment of the quality of life, both in general terms and by division into individual domains. This finding may indicate excessive effort associated with the performed activities. Similarly, other studies have shown that nurses are a professional group whose work is associated with a forced position, causing pathological spine lesions, pain and disability [31-33]. A report by Fidecki et al. regarding nurses and paramedics working in such departments as neurology, neurosurgery and orthopaedy with traumatology, indicated that feeling severe pain and II and III degree of disability according to Fairbank are closely associated with the workplace and work experience [33]. Similar results were obtained by Maciuk et al. among group of nurses and Nowotny et al. in a group of physiotherapists and midwives $[34,35]$. In a study by Nowotny et al., the body posture of employees was assessed during the performance of professional activities. Hyperextension and excessive flexion in the lumbar and sacral segment of the spine were found, and the pain on the VAS scale was estimated at 4-7 [35]. Chiou et al., analyzing a group of 3,159 nurses, found that lower back pain was associated with weight lifting, working time, age, BMI and work habits. Nurses in their study, as in observations by the authors of the presented study, used physical therapy and rehabilitation [17]. Kulczycka et al., using the PSI questionnaire for paramedics during their work, showed a relationship between age and experiencing pain with working in several places, and fatigue. Moreover, it was found that paramedics working in accordance with the principles of ergonomics experienced back pain less often [36]. Longitudinal studies by Gold et al. indicated that the incidence of lower back pain decreased between baseline and after 2 years, as well as 5-6 years after the implementation of the Safe Resident Handling Program SRHP in nursing homes [37]. The occurrence of lower back pain was positively associated with combined physical and psychological exposures, work requirements and previous back injury. The frequent use of patient lifting equipment and intensive aerobic exercise proved to be protective. The 
introduction of SRHP in nursing homes led to a reduction in injury recurrence, which had a positive effect on reducing the frequency of sick leaves [38].

Limitations of the study. One of several limitations to this study concerns the characteristics of the studied group because physicians of the specialties involving a forced position at work were not included. The second limitation is the study group size, which indicates pilot evaluation; however, the obtained results are comparable with those included in meta-analyzes and systematic reviews published by other authors.

\section{CONCLUSIONS}

1. The obtained results show the occurrence of a health problem - pain in various sections of the spine associated with professional activities. Overload of the spine during work performance has a great impact on the appearance of pain.

2. Pre-graduate education should introduce occupational ergonomics classes. Healthcare workers should be included in a preventive programme, and should have the possibility to attend systematic occupational ergonomics courses. Healthcare facilities should be retrofitted with equipment enabling work in accordance with the principles of ergonomics.

3. It would be beneficial for future epidemiological studies to focus on this category of research to determine the prevalence of lower back pain. This could form the basis for assessing the parameters that increase the frequency of lower back pain, as well as reducing or eliminating such factors.

4. The ODI questionnaire, together with the VAS method and scales for testing the quality of life, are useful tools in the clinical assessment of patients with back pain.

\section{REFERENCES}

1. van Dieën JH, Kuijer PP, Burdorf A, Marras WS, Adams MA. Nonspecific low back pain. Lancet. 2012; 379(9829): 1874; author reply 1874-5. https://doi.org/10.1016/S0140-6736(12)60803-4

2. Eurofund, Sixth European Working Conditions Survey - Overview report (2017 update). Publications Office of the European Union. Luxemburg: European Foundation for the Improvement of Living and Working Conditions, 2017. https://op.europa.eu/en/ publicationdetail/-/publication/b4f8d4a5-b540-11e7-837e-01aa75ed71a1/ language-en /format-PDF/source-44702858 (access: 2019.10.24)

3. Rubin DI. Epidemiology and risk factors for spine pain. Neurol Clin. 2007; 25(2): 353-371. https://doi.org/10.1016/j.ncl.2007.01.004

4. Saragiotto BT, Maher CG, Yamato TP, Costa LO, Menezes Costa LC, Ostelo et al. Motor control exercise for chronic non-specific low-back pain. Cochrane Database Syst Rev. 2016; (1): CD012004. https://oi. org/10.1002/14651858.CD012004

5. Shemshaki H, Nourian SM, Fereidan-Esfahani M, Mokhtari M, Etemadifar MR. What is the source of low back pain? J Craniovertebr Junction Spine. 2013; 4(1): 21-24. doi: 10.4103/0974-8237.121620

6. Kassolik K, Rajkowska-Labon E, Tomasik T, Pisula-Lewadowska A, Gieremek K, Andrzejewski W et al. Recommendations of the Polish Society of Physiotherapy, the Polish Society of Family Medicine and the College of Family Physicians in Poland in the field of physiotherapy of back pain syndromes in primary health care. Fam Med Primary Care Rev. 2017; 19(3): 323-334. https://doi.org/10.5114/fmpcr.2017.70453

7. Airaksinen O, Brox JI, Cedraschi C, Hildebrandt J, Klaber-Moffett J, Kovacs $\mathrm{F}$ et al. Chapter 4 European guidelines for the management of chronic nonspecific low back pain. Eur Spine J. 2006; 15 Suppl 2(S2): S192-300. https://doi.org/10.1007/s00586-006-1072-1
8. Wong WS, Chen PP, Yap J, Mak KH, Tam BK, Fielding R. Chronic pain and psychiatric morbidity: a comparison between patients attending specialist orthopedics clinic and multidisciplinary pain clinic. Pain Med 2011; 12: 246-259. https://doi.org/10.1111/j.1526-4637.2010.01044.X

9. Choi BK, Verbeek JH, Tam WW, Jiang JY. Exercises for prevention of recurrences of low back pain. Cochrane Database Syst Rev. 2010; (1): CD006555, https://doi.org/10.1002/14651858.CD006555.pub2

10. Smith JA, Osborn M. Pain as an assault on the self: An interpretative phenomenological analysis of the psychological impact of chronic benign low back pain. Psychology \& Health. 2007; 22: 517-534. https:// doi.org/10.1080/14768320600941756

11. Jaracz K, Kalfoss M, Gorna K, Baczyk G. Quality of life in Polish respondents: psychometric properties of the Polish WHOQOL-Bref. Scand J Caring Sci. 2006; 20(3): 251-260, https://doi.org/10.1111/j.14716712.2006.00401.x

12. de Campos TF. Low back pain and sciatica in over 16s: assessment and management NICE Guideline [NG59]. J Physiother. 2017; 63(2): 120. https://doi.org/10.1016/j.jphys.2017.02.012

13. CDC. Prevalence and most common causes of disability among adultsUnited States, 2005. MMWR Morb Mortal Wkly Rep. 2009; 58(16) 421-426.

14. Vos T, Flaxman AD, Naghavi M, Lozano R, Michaud C, Ezzati M et al. Years lived with disability (YLDs) for 1160 sequelae of 289 diseases and injuries 1990-2010: a systematic analysis for the Global Burden of Disease Study 2010. Lancet. 2012; 380(9859): 2163-2196. https://doi. org/10.1016/S0140-6736(12)61729-2

15. Kuijer PP, Verbeek JH, Seidler A, Ellegast R, Hulshof CT, Frings-Dresen $\mathrm{MH}$ et al. Work-relatedness of lumbosacral radiculopathy syndrome. Review and dose-response meta-analysis. Neurology. 2018; 91(12): 558-564.https://doi.org/ 10.1212/01. wnl.0000544322.26939.09

16. Sierakowska M, Doroszkiewicz H, Kondzior D, Klimaszewska K, Jemieljańczuk Z, Dolińska C. Prewencja dysfunkcji ze strony układu mięśniowo-szkieletowego na przykładzie realizacji Programu profilaktyki zespołów bólowych kręgosłupa u personelu pielęgniarskiego [Prevention of the musculoskeletal system's dysfunction based on the example of Prevention program of spinal pain syndrome in nursing staff]. Med Pr. 2019; 70(2): 189-199. https://doi.org/10.13075/mp. 5893.00801. (in Polish)

17. Chiou WK, Wong MK, Lee YH. Epidemiology of low back pain in Chinese nurses. Int. J Nurs Stud. 1994; 31(4): 361-368.

18. Maul I, Läubli T, Klipstein A, Krueger H. Course of low back pain among nurses: a longitudinal study across eight years. Occup Environ Med. 2003; 60(7): 497-503.

19. Glover W, McGregor A, Sullivan C, Hague J. Work-related musculoskeletal disorders affecting members of the Chartered Society of Physiotherapy. Physiotherapy 2005; 91(3): 138-147. https://doi. org/10.1016/j.physio.2005.06.001

20. Cheung K. The incidence of low back problems among nursing students in Hong Kong. J Clin Nurs. 2010; 19(15-16): 2355-2362. doi: 10.1111/j.1365-2702.2009.03091.x

21. Wnukowski K, Kopański Z, Brukwicka I, Sianos G. Zagrożenia towarzyszące pracy ratownika medycznego-wybrane zagadnienia [The dangers of medical rescue work - selected issues]. J Clin Healthc. 2015; 3: 10-16. (in Polish)

22. Corbeil P, Plamondon A, Tremblay A, Prairie J, Larouche D, HeggDeloye S. Measurement of Exposure to Musculoskeletal Risk Factors Among Emergency Medical Technician-Paramedics. Institut de recherche Robert-Sauvé en santé et en sécurité du travail (IRRST), Montreal, Québec 2018 (access 2019.10.21) Available from: https://www. irsst.qc.ca/media/documents/PubIRSST/R-1006.pdf?v=2019-10-26

23. Raport Naczelnej Rady Pielęgniarek i Położnych. Zabezpieczenie społeczeństwa polskiego w świadczeniu pielęgniarek i położnych. Warszawa: Naczelna Izba Pielęgniarek i Położnych, 2017 (access 2019.10.21). Available from: https:/nipip.pl/wp-content/ uploads/2017/03/Raport_druk_2017.pdf

24. Matsudaira K, Shimazu A, Fujii T, Kubota K, Sawada T, Kikuchi T et al. Workaholism as a risk factor for depressive mood, disabling back pain, and sickness absence. PLoS One. 2013; 8(9): e75140. https://doi. org/10.1371/journal.pone.0075140

25. Bigos SJ, Holland J, Holland C, Webster JS, Battie M, Malmgren JA. High-quality controlled trials on preventing episodes of back problems: systematic literature review in working-age adults. Spine J. 2009; 9(2): 147-168. https://doi.org/10.1016/ j.spinee.2008.11.001

26. Misiołek H, Mayzner-Zawadzka E, Dobrogowski J, Wordliczek J. Zalecenia 2011 postępowania w bólu ostrym i pooperacyjnym. Ból. 2011; 12(2): 9-34. [in Polish]

27. Fairbank JC, Pynsent PB. The Oswestry Disability Index. Spine. 2000; 25(22): 2940-2953. 
28. Wołowicka L, Jaracz K. Polska wersja WHOQOL 100 i WHOQOL Bref. In: Wołowicka L, editor. Jakość życia w naukach medycznych, Poznań; 2001. [in Polish]

29. Coenen P, Gouttebarge V, van der Burght AS, van Dieën JH, FringsDresen MH, van der Beek AJ et al. The effect of lifting during work on low back pain: a health impact assessment based on a meta-analysis. Occup Environ Med. 2014; 71(12): 871-877. http://dx.doi.org/10.1136/ oemed-2014-102346

30. MZDFEi e-Zdrowia. Ogólnopolski program profilaktyki przewlekłych bólów kręgosłupa. 2019-2023 (access 2019.10.21). Available from: https://pacjent.gov.pl/sites/default/files/ 2019-09/ppz_choroby_ kregoslupa.pdf.

31. Jabłońska R, Gralik M, Królikowska A, Haor B, Antczak A. The problem of back pain among nurses of neurology and neurosurgery wards. JNNN. 2016; 5(3): 84-91.

32. Kupcewicz E. Jakość życia pielęgniarek a strategie radzenia sobie ze stresem doświadczanym w środowisku pracy [Quality of life of nurses and strategies for coping with stress experienced in the work environment]. Med Og Nauk Zdr. 2017; 23(1): 62-67. https://doi. org/10.5604/20834543.1235627. (in Polish)

33. Fidecki W, Wysokiński M, Ochap M, Wrońska I, Przylepa K, Kulina $\mathrm{D}$ et al. Selected aspects of life quality of nurses at neurological wards. JNNN. 2016; 5(4): 151-155. http://dx.doi.org/10.15225/PNN.2016.5.4.4
34. Maciuk M, Krajewska-Kulak E, Klimaszewska K. Samoocena występowania zespołów bólowych kręgosłupa u zawodowo czynnych pielęgniarek [Self-assessment of low back pain incidence in professionally active nurses]. Probl Hig Epidemiol. 2012; 93(4): 728-738. (in Polish)

35. Nowotny J, Nowotny-Czupryna O, Brzęk A, Kowalczyk A, Czupryna K. Body posture and syndromes of back pain. Ortop Traumatol Rehabil. 2011; 13(1): 59-71. https://doi.org/10.5604/ 15093492.933788

36. Kulczycka K, Grzegorczyk-Puzio E, Stychno E, Piasecki J, Strach K. Wpływ pracy na samopoczucie ratowników medycznych [Effect of work on general wellbeing of paramedics]. Med Og Nauk Zdr. 2016; 22(1): 66-71. https://doi.org/10.5604/20834543.1198726. (in Polish)

37. Gold JE, Punnett L, Gore RJ, ProCare Research Team. Predictors of low back pain in nursing home workers after implementation of a safe resident handling programme. Occup Environ Med. 2017; 74(6): 389-395. http://dx.doi.org/10.1136/oemed-2016-103930

38. Kurowski A, Pransky G, Punnett L. Impact of a Safe Resident Handling Program in Nursing Homes on Return-to-Work and Reinjury Outcomes Following Work Injury. J Occup Rehabil. 2019; 29(2): 286-294. https://doi.org/10.1007/s10926-018-9785-7

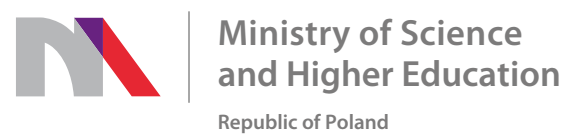

Generation of the DOI (Digital Object Identifier) - task financed under the agreement No. 618/P-DUN/2019 by the Minister of Science and Higher Education 